\title{
Widening the scope: linking coastal sedimentation with watershed dynamics in Java, Indonesia
}

\author{
Martin C. Lukas ${ }^{1}$
}

Received: 2 February 2015/Accepted: 28 September 2016/Published online: 8 December 2016

(c) The Author(s) 2016. This article is published with open access at Springerlink.com

\begin{abstract}
Watershed processes and their effects on coasts are shaped by numerous interacting natural and societal factors. The knowledge of these factors and processes is often limited. This makes the field prone to politicisations with debates, research, and interventions being confined to a few selected factors. Debates on the causes of high river sediment loads and coastal sedimentation in Java have focussed on rainfed agriculture on peasants' private lands, while other drivers have been neglected. This has undermined the effectiveness of watershed management. This paper links the sedimentation of the Segara Anakan lagoon on Java's south coast with landscape characteristics and transformations in its catchment. Three-fourths of the lagoon have silted up since 1857/60. This is the result of a much broader range of drivers than commonly assumed to date. In addition to rainfed agriculture on peasants' private lands, these drivers include coffee cultivation, timber extraction, plantation development, and in-migration in the
\end{abstract}

The article builds on research that the author begun when he was affiliated with the Leibniz Center for Tropical Marine Ecology Bremen GmbH (ZMT), Fahrenheitstraße 6, 28359 Bremen, Germany.

Editor: Virginia Burkett.

The supplementary material also contains the Indonesian version of the article.

Electronic supplementary material The online version of this article (doi:10.1007/s10113-016-1058-4) contains supplementary material, which is available to authorized users.

\section{Martin C. Lukas}

martin.lukas@uni-bremen.de

1 University of Bremen, MARUM - Center for Marine Environmental Sciences, Sustainability Research Center (artec), Enrique-Schmidt-Str. 7, 28359 Bremen, Germany late nineteenth and early twentieth century; erosion on contested state forest and plantation lands; state forest management practices; slope cuts to enlarge agricultural fields; agriculture in riparian zones; erosion from roads, trails, and settlements; river channel and floodplain modifications; and volcanic eruptions. The choice and expectations of societal responses aimed at reducing river sediment loads and coastal sedimentation hence need to be reconsidered, and related debates and research agendas must be broadened.

Keywords Sediment sources $\cdot$ Sediment yield $\cdot$ Soil erosion · Environmental history · Watershed management . Segara Anakan lagoon

\section{Introduction}

Watershed and coastal management is confronted with dynamics that are often only rudimentarily understood. Interlinked processes, such as erosion, sediment transport, and coastal sedimentation, are influenced by numerous natural and anthropogenic factors, which interact over various scales. Knowledge of these factors is crucial for environmental management. For example, sediment mitigation requires knowledge of the sediment sources, sinks, and fluxes within a watershed and of related natural and anthropogenic drivers (Milliman and Syvitski 1992; Meybeck and Vörösmarty 2005; Walling and Collins 2008). Yet, such knowledge is limited in most parts of the world (ibid.). This particularly applies to societal factors. The directly observable anthropogenic effects on environmental processes are linked to societal structures and dynamics that are vaguely understood. Disciplinary boundaries and discursive framings obstruct our view in such contexts by 
confining inquiries to a few processes or drivers and preventing others from being debated, explored, and addressed-a phenomenon known as problem closure (Hajer 2000). This can undermine the environmental outcomes of watershed management and lay the ground for unrealistic expectations thereof. Research that widens the scope to the broad range of watershed characteristics and dynamics and related societal factors is crucial in such contexts.

This particularly applies to the island of Java. The island constitutes a global hot spot of sediment transport to the oceans (Milliman et al. 1999; Milliman and Farnsworth 2011). River sediment loads (RSL) are naturally high due to tectonic activity, the mountainous relief, and high-intensity rainfalls. The interaction of this dynamic environment with anthropogenic modifications results in high erosion and sedimentation rates (Lavigne and Gunnell 2006). Upland erosion and the sedimentation of reservoirs, irrigation schemes, and coastal ecosystems have been targeted through field terracing and tree planting programmes since the 1970s. Despite substantial investments, the effects of these efforts on RSL are unknown and regarded as limited (Schweithelm 1988; Diemont et al. 1991). This has been attributed to shortcomings in programme design and implementation, land tenants' limited scope to invest into soil conservation, and price guarantees for cassava (USAID 1985; Huszar and Cochrane 1990; Purwanto 1999; Van Dijk 2002; ADB 2006).

More fundamentally, debates, research, and political interventions have for decades focussed on upland peasants' private plots, while neglecting other causes of high RSL. This has a priori limited the effectiveness of watershed management. While erosion on upland peasants' private plots has been the subject of much research (e.g. Repetto 1986; Donner 1987; Magrath and Arens 1989; Palte 1989; Barbier 1990; Van Dijk 2002; Rudiarto and Doppler 2013), knowledge of other sediment sources and related societal drivers is scarce. Also historical time series of RSL are lacking or unreliable. Following years of investment into upland conservation in the catchment of the Segara Anakan lagoon (SAL), one of Java's long-standing priority areas for watershed management, an assessment of the USAID-funded Citanduy-II Project revealed that "[1]ittle has been learned about the sources of erosion. [...] [T] here is much opinion but little fact" (USAID 1985:9). The project's watershed consultant judged "that privately owned upland farms [the project's main target] contribute a small part of the [river] sediment load" and that "[s]edimentation can only be reduced if its sources are identified [...]" (Schweithelm 1988:6). Sediment sources have since been assessed in a few small subcatchments elsewhere in Java (Nibbering and de Graaf 1998; Purwanto 1999; Van Dijk 2002; Rijsdijk 2005; Rijsdijk et al. 2007a, b). Yet, for larger river basins, knowledge is still very limited.
This also applies to the catchment of the SAL. This lagoon has rapidly shrunk due to riverine sediment input. No watershed-wide analysis of sediment sources and their causes has been undertaken. The explanatory value of two sediment analyses (Dewi et al. 1979; Kastanja 2001) with regard to the temporal dynamics and causes of sedimentation is limited. In the absence of concrete knowledge, lagoon sedimentation has mainly been linked to erosion on upland peasants' private plots.

This paper contributes knowledge on the dynamics and drivers of high RSL and coastal sedimentation. It links a historical cartographic analysis of shoreline aggradation in the SAL with landscape characteristics and transformations in its catchment and thereby directs attention to a range of so far neglected drivers of lagoon sedimentation.

\section{Materials and methods}

\section{Study area}

The SAL, a shallow lagoon on Java's south coast, forms the estuary of the Citanduy, Cibeureum, and Cikonde Rivers (Fig. 1, Online Resource 2). It has rapidly silted up. Political interventions, including the USAID-funded Citanduy-II project and the ADB-funded Segara Anakan Conservation and Development Project, aimed at halting sedimentation through dredging, river diversions, and watershed conservation. Much research has been conducted in the lagoon (e.g. Bird et al. 1982; White et al. 1989; Olive 1997; Jennerjahn and Yuwono 2009). In contrast, the lagoon's catchment and hence the drivers of lagoon sedimentation have been the subject of very little study. The catchment area comprises $\approx 450,000$ ha. It is dominated by volcanic mountains in its north-western part, sedimentary mountain ranges in its north-eastern and southern parts, and a plain to hilly central river basin. The major land uses comprise wet rice cultivation, rainfed agriculture, settlements with house gardens, peasants' (mixed) forests, and state forests. Most of the area belongs to the districts of Tasikmalaya and Ciamis and the municipalities of Tasikmalaya and Banjar in the province of West-Java (formerly these areas were part of the Priangan Regency), and the district of Cilacap in the province of Central-Java (Online Resource 2).

\section{Methods}

Based on historical maps and satellite images (see Online Resource 3), the change in the SAL's water surface area was reconstructed for the period 1857/60-2013. A discussion of the historical maps, their production, and accuracy is contained in Lukas (2014a, 2015). The maps and satellite images were georectified using ArcGIS. On their basis, 
historical shorelines were hand-outlined and water surface areas determined. Incorporating the georectification and a digitisation-operator error, an areal error was determined as a measure of the results' reliability (Online Resource 3). This areal error, depicted in Fig. 2, clearly overestimates the uncertainty of the results, as the perimeter used for its calculation includes shoreline sections not affected by aggradation.

The change in the water surface area is not directly proportional to RSL or sediment volumes deposited. Determining the second requires historical bathymetric data. Such data exist only for the past 2.5 decades (see White et al. 1989; Holtermann et al. 2009). Determining the first for historical periods is unfeasible as the proportions of riverine sediments deposited in the lagoon and those transported out into the ocean change over time. Despite these limitations, the change in the lagoon's water surface area can be assumed to provide a rough picture of the temporal dynamics of riverine sediment input, albeit not with direct proportionality.

Information about historical watershed characteristics and transformations was compiled from different strains of literature and historical documents. Changes in settlement areas and river courses were analysed using historical and contemporary topographic maps. For this purpose, 23 map sheets based on surveys in 1924-1926 (U.S.-Army 193842) and 41 sheets of the most recent topographic maps (BAKOSURTANAL 1997-99) were scanned and georectified. Using the classification tools in ArcGIS, the settlement areas were extracted from each map sheet, converted into shapefiles, simplified, manually corrected, combined, and their total sizes calculated. As part of a broader research project, these and other maps were overlayed with satellite images (Landsat MSS, TM, ETM+; SPOT 2/5; Google maps), taken 1976-2015, to identify land use/land cover changes. land use/land cover and other landscape features were mapped on the ground, and land use practices were observed throughout the lagoon's catchment. Socialscientific case studies were carried out to identify the causes of land use/land cover and other environmental changes. These case studies involved semi-structured interviews with representatives of governmental and nongovernmental organisations, the state forest corporation, village governments, farmers, and other village residents.

The availability and quality of historical maps and records confined the research to the past 1.5 centuries. This period covers a transition from a mainly nature-dominated to a human-dominated landscape, which supports an appraisal of the various drivers of change (Messerli et al. 2000). It is the period that Cooke (1992) referred to as the 'recent past' that is often neglected in favour of studies on either long-term or contemporary environmental dynamics.

\section{Results and discussion}

\section{Temporal dynamics of lagoon shoreline aggradation}

The historical cartographic reconstruction of shoreline aggradation depicts a dramatic decline of the SAL's water surface area from 8600 to 2200 ha since $1857 / 60$ (Fig. 1+2, Online Resources $3+4$ ). This process accelerated until the 1980/90s and slowed down thereafter. The increasing lagoon aggradation rates conform to the accelerated growth of river deltas on Java's north coast between 1857/1922 and 1922/1946 (Hollerwöger 1964).

\section{Drivers of lagoon sedimentation}

Lagoon sedimentation is the result of numerous historical and contemporary drivers (Fig. 1). Rainfed agriculture on peasants' private plots is one of them, but not the single-most important one. My analyses of historical maps and satellite images, watershed-wide mapping, and social-scientific case studies concurrently showed that rainfed agriculture was expanded until the 1970-1990s. Yet, field terracing and recently increasing tree cover have reduced erosion on some of these lands. In contrast, tree cover declined in state forest and plantation lands. My satellite image analysis and land cover mapping identified these lands as hot spots of land cover change and erosion. Social-scientific case studies in these areas disclosed conflicts over land and forest resources as the major cause for this. In addition, the satellite image analysis and field observations revealed state forest management practices as an important cause of land cover change and erosion. Observations and interviews also identified slope cuts to enlarge agricultural fields, agriculture in riparian zones, and erosion in settlements and on roads, trails, and embankments as major sediment sources. In addition, various historical watershed modifications and volcanic eruptions appear to have contributed to lagoon sedimentation. The following sections analyse these drivers in detail. They combine knowledge from literature and documents and results of my own empirical work.

\section{Historical watershed transformations}

The most profound environmental transformations in the lagoon's catchment occurred between the mid-nineteenth century and the 1920s. Until then, the conversion of Java's natural forests was relatively slow and concentrated in the lowlands (Smiet 1990). The uplands of the study area were clearly less affected by anthropogenic impacts than other parts of the island. This region was marked by low 
Fig. 1 The Segara Anakan lagoon on the south coast of Java has rapidly shrunk due to sediment input from the Citanduy, Cibeureum, and Cikonde Rivers. This is the result of a broad range of drivers that have increased sediment generation and transport. The map series illustrates the change in the water surface area of the Segara Anakan lagoon over time. Base map: SRTM (Shuttle Radar Topography Mission), available from the US

Geological Survey. Historical shorelines are based on the maps and satellite images listed in Online Resource 3. A higher resolution map of the area and an animation-like illustration of shoreline aggradation are contained in Online Resources 2 and 4
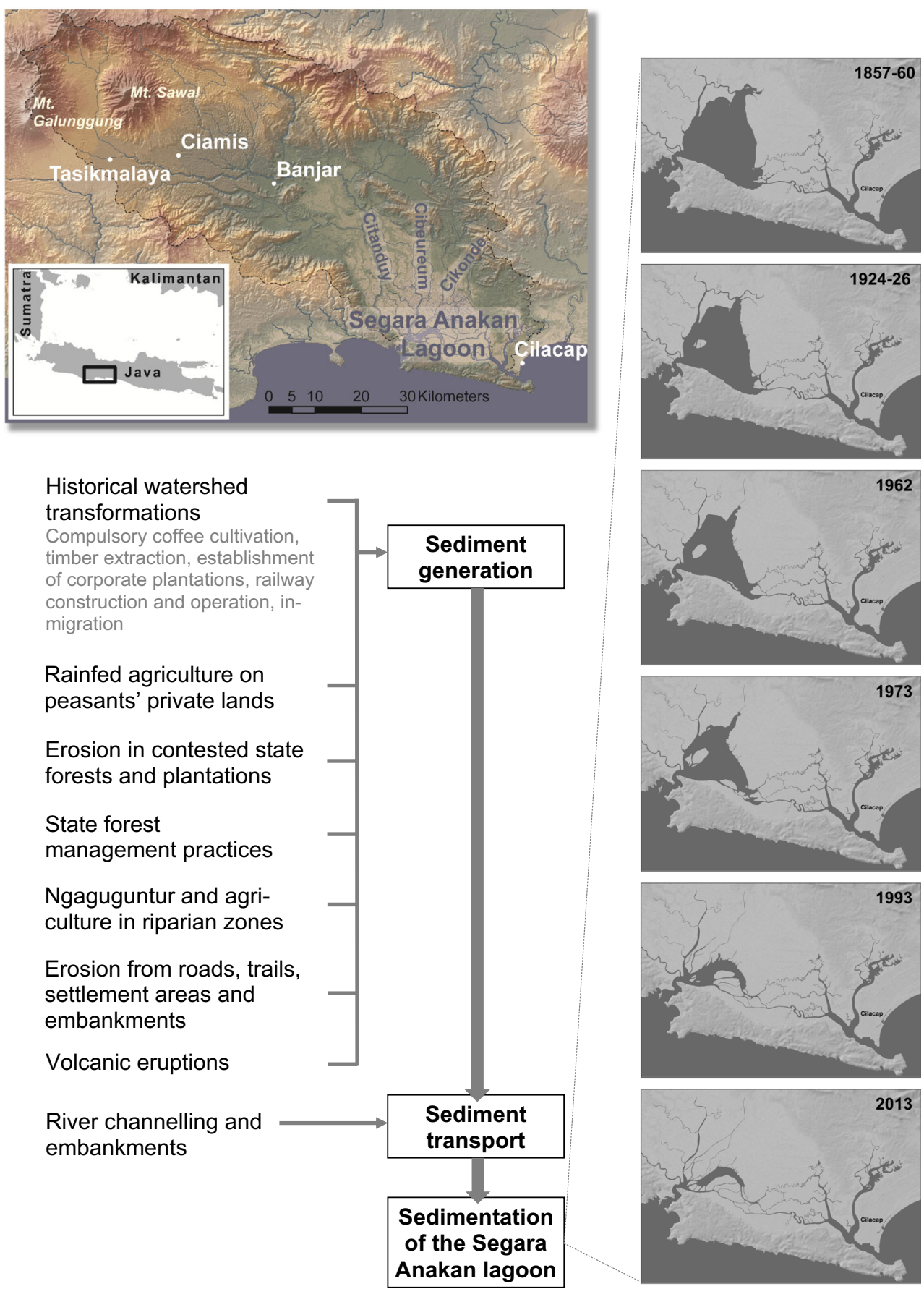

population densities, large forest areas, and shifting cultivation (Geertz 1971).

Compulsory coffee cultivation likely had the earliest profound impact on erosion rates. Coffee was the major export crop from the Netherlands East Indies and the principle source of profit for the Regents and the Dutch (Fasseur 1992). Priangan's uplands were Java's main coffee growing region, with 56-65\% of the population assigned to compulsory cultivation (Fasseur 1992). To set up "coffee gardens", the forest was completely cleared or the coffee was planted on abandoned swidden fields. This resulted in soil degradation and erosion (Van Schaik 1986). Once the coffee trees were old and the soils degraded, the land was transferred to peasants for cultivation, while additional land was opened up for new coffee gardens (Van Schaik 1986; Nibbering 1988). The coercive cultivation regime also made peasants migrate and open up land in remote areas (Palmer 1959). The coffee regime was hence a main driver of deforestation and soil degradation in the late nineteenth century (Van Schaik 1986). It appears to 
have raised erosion rates by the practices of coffee cultivation, by promoting permanent rainfed agriculture and by triggering migration.

From the mid-nineteenth century to the 1920s, timber extraction resulted in forest degradation and likely raised erosion rates. Timber demand for ship building, infrastructure, houses, furniture, export, and export crop processing rose massively during the nineteenth century (Boomgaard 1988). As the teak forests elsewhere in Java started to be depleted, this rising demand was increasingly met by exploitation of the non-teak forests. Hence, timber extraction rapidly increased in parts of the study area from the mid-nineteenth century (Dienst van het Boschwezen 1905, 1907, quoted in Van Goor et al. 1982).

From the 1860s, the construction and operation of railways contributed to deforestation by increasing timber and fuelwood demand and by providing access to remote areas (Boomgaard 1988). A railway line from Jakarta/ Bandung across the SAL's entire catchment via Tasikmalya, Ciamis, and Banjar to Yogyakarta was opened by 1894 (AGS 1945). Its construction created slope cuts, which must have been a substantial sediment source during the first years (cf. AGS 1945) and some of which are erosion-prone until now. The new railways also facilitated in-migration, the transport of export crops, and the establishment of plantations and cassava flour mills, thereby promoting erosion-prone rainfed agriculture (Van Doorn and Hendrix 1983).

Additional forests were cleared for the establishment of plantations. The Agrarian Law of 1870 declared unoccupied land as government land, leasable to entrepreneurs. This led to a surge of export-oriented estate development in the following decades. My analysis of the lists and maps of historical plantations contained in Knaap et al. (2007) and their overlay with watershed boundaries revealed that at least 25,000 ha or $5.4 \%$ of the SAL's catchment area was converted into plantations. The replacement of forests by estate crops likely raised erosion rates, at least temporarily.

The demand of plantation labourers contributed to inmigration into this sparsely populated area. Also feudal duties, coercive export crop cultivation and forced labour in the lowlands made people flee to the uplands (Raffles 1817; Boomgaard and van Zanden 1990). The abolishment of the Kultuurstelsel, which had confined the growing population to existing arable land, caused a "spatial outburst" of people towards the uplands (Palte 1989:42). New roads and railways facilitated this. These factors caused substantial in-migration into the lagoon's catchment between the 1860s and 1920s. Elder residents and village representatives, interviewed as part of my case studies, knew from their parents or from village records that large numbers of people moved in from the lowlands. The population of Priangan increased 24-fold between 1815 and
1930 (Widjoyo 1970). This accelerated the conversion of forests into other, mostly more erosion-prone, types of land cover.

Deforestation rates peaked in the late nineteenth/early twentieth century. Between 1898 and 1936, the area of non-teak forests in Java declined from 4 to 1.8 million ha (Smiet 1990). The factors explored above and forest policies limiting peasants' access to forest resources (Peluso 1992) contributed to land scarcity. Consequently, migration to the uplands declined in the 1920s. By the 1930s, almost the entire area of Java was divided between state forests, corporate estates, and peasants' land (Palte 1989). Shifting cultivation was gradually abandoned, and peasants' private lands have since been dominated by wet rice cultivation, rainfed agriculture, and mixed forests.

\section{Rainfed agriculture on peasants' private lands}

Whereas wet rice cultivation and mixed forests belong to the most soil conserving cropping systems in the humid tropics, rainfed agriculture is prone to soil erosion (Scholz 1998). In contrast to other sediment sources, peasants' rainfed agricultural plots have been targeted by watershed conservation programmes and have been the subject of considerable research.

The expansion of rainfed agriculture coincided with the transformations explored above. In the whole of Java, it rose by $177 \%$ between 1883 and 1913 (Palte 1989). This trend continued during the following 1.5 decades, triggered by food shortages and rising agricultural prices (Boomgaard and van Zanden 1990). My analyses of historical and recent topographic maps and satellite images and the social-scientific case studies conformingly showed that the expansion of settlements and rainfed agriculture on the cost of forest, bush and grassland continued in parts of the study area until the 1970s, in some areas until the 1980/90s (see Online Resource 5 for an example).

From the 1970/80s, the uplands have been targeted by tree planting and field terracing programmes. My watershed-wide land use mapping showed that most upland agricultural land owned by peasants is terraced. Yet, soil erosion remains an issue, also on terraced land. I observed this particularly in the eastern parts of the catchment where easily erodible sedimentary soils predominate. In line with this observation, Schweithelm (1988) noted that the terracing programmes had shown little effect in these areas. It has been observed that terracing alone, if not combined with other soil conservation measures, such as mulching, denser vegetation, or reduced tillage, might not effectively reduce erosion (Schweithelm 1988; Purwanto 1999; Van Dijk 2002; Sidle et al. 2006). Returning crop residues to the soil in the form of mulch or compost, as commonly practiced in organic agriculture, instead of burning them, which 
is common throughout Java, could reduce erosion. Recent initiatives to promote organic farming by the agricultural extension services are encouraging in this respect.

My satellite image analysis and the social-scientific case studies conformingly revealed that the watershed programmes raised tree cover on peasants' private lands only in a few locations between the 1970s and 1990s. However, since the early 2000s, tree cover has tended to increase. This is visible in satellite images and was confirmed through interviews. This trend was attributed to various factors, including the increasing profitability of tree crops, nonagricultural incomes, experiences with soil degradation, the presence of timber marketing opportunities, and new bottom-up-oriented incentives by governmental and nongovernmental organisations. Some previously bare slopes covered by my case studies had repeatedly been targeted by watershed programmes without much success, but are now covered with trees (see Online Resource 6 for an example).

To sum up, rainfed agriculture on peasants' private lands has contributed to high RSL during the past 1.5 centuries. The overall erosion potential of peasants' lands in the study area increased between the mid-nineteenth century and the 1970s. Land terracing and increasing tree cover appear to have reduced the erosion potential on some of these lands since the 1970s/2000s.

\section{Erosion in contested state forests and plantations}

Some of the most erosion-prone lands that I identified through satellite image analyses and land cover mapping are situated in state forest and plantation territories. My social-scientific case studies revealed conflicts over the access to and control of these lands and forest resources as the main cause for this. These conflicts can only be understood by taking into account the historical trajectory of forest and plantation management.

The state forests alone constitute almost one-fourth of Java's land area. They were demarcated by the colonial forest administration, and peasants' traditional forest uses were increasingly criminalised in the nineteenth century (Peluso 1992). In the light of dwindling timber supplies, tight forest management was to sustain production (Boomgaard 1988; Peluso 1992). From the early twentieth century, concerns over negative hydrological effects of upland degradation, including on former coffee plantations, became an additional rationale for the expansion and exclusive management of state forests (Kerbert 1916; Roessel 1927; Steup 1927; De Haan 1936; Coster 1938).

Since their demarcation until today, the state forests have been contested by peasants. Though it was declared illegal, peasants continued to use forest lands and resources, on which many of them depended (Peluso 1992). As a result of timber and fuel wood thefts, burning, grazing, and crop cultivation, many state forests were degraded throughout the twentieth century (Nibbering 1988; Smiet 1990; Peluso 1992). The extent of degradation varied over time. By 1940, one-third of Java's protected forests were deforested or degraded (Smiet 1990). Degradation then peaked during the Japanese occupation 1942-1945 and during the following early years of national independence. The absence of forest and plantation management and control during this period, the need to maximise food production, and the high demand for castor oil and timber for the Japanese army resulted in widespread state-initiated and spontaneous conversions of forests and plantations into arable land, leading to soil erosion (Nibbering 1988; Palte 1989). About $18 \%$ of Java's pre-war forests were cleared between 1942 and 1950, leaving only $17 \%$ of the land area forested (Prakoso 1954). Despite armed policing during Suharto's New Order era from the mid-1960s until 1998, forest degradation remained an issue throughout Java (Peluso 1992; Nibbering and de Graaf 1998).

Degradation of state forests and plantations peaked again between 1998 and the early 2000s, when vast areas were plundered during the political turmoil following the fall of the New Order regime. My analysis of satellite images, land use mapping, and interviews conformingly revealed that in parts of the SAL's catchment, up to onehalf of the state forests were cut down (Online Resource 7). Local residents, with people from towns who provided chain saws and trucks, and spearheaded by influential individuals, sometimes from the forest administration itself, used the opportunity of the political transition to plunder state forests and plantations. Some of my respondents noted that, following a history of exclusive, repressive forest management, the plundering was a demonstration of power by the people. It initiated renegotiations of established patterns of forest access and control and resulted in large-scale forest degradation and soil erosion. My observations, mappings, and interviews exposed state forest lands as the most significant source of riverine sediments in parts of the SAL's catchment.

Future land use and hence the erosion potential of these lands depend on the outcomes of ongoing struggles over resource access and control. Some of the lands have been reforested by the state forest corporation. Some of them are managed through "community forestry" schemes, whereby peasants receive part of the revenue, are responsible for safeguarding the trees, and have the possibility to cultivate crops, while the forest corporation retains control over the land and major management decisions. The performance of these schemes was mixed at the time of field research. Their top-town character, the peasants' lack of a sense of ownership for forests under the domain of the forest corporation, and the challenge of building trustful relations between peasants and the corporation are reflected in 
scattered tree cover and soil erosion. Finally, some of the cleared state forest and plantation lands remained as treeless, highly erosion-prone sites, cultivated by peasants who claimed ownership over the land. These claims are rooted in displacements of peasants or entire villages in the 1950/60s (see Lukas 2014b) or in illegitimate expansions of former Dutch plantations when they were transferred into Indonesian ownership. Until land conflicts are resolved, the peasants use these lands for cultivation but hesitate to invest in soil conservation. That is, erosion on these lands is the direct outcome of historically rooted struggles over land and forest resources.

\section{State forest management practices}

Rigid control and tight management of the state forests has been the core thrust of watershed protection in Java since the 1920s. Yet, the teak and pine plantations that constitute most of the state forests and the state forest corporation's timber harvesting methods deserve critical appraisal.

My analysis of satellite images, land cover mapping, and interviews showed that rotational clear cuts are the forest corporation's standard timber harvesting method (Online Resource $8 \mathrm{a}+\mathrm{b}$ ). I observed that during clear cuts not only the trees and potentially existing understorey vegetation were cut, but also the tree stumps and roots were removed, resulting in the entire plot being dug up leaving the exposed mineral soil vulnerable to erosion during the next heavy rainfall event. I found such plots on very steep slopes and in direct proximity to streams, which results in high sediment delivery ratios. The effects of these timber harvesting methods on erosion and RSL have barely been discussed to date. The few documentations existing include a photograph in Lavigne and Gunnell (2006:92) that depicts substantially sized landslides on mountainous state forest land near Cilacap following a clear cut.

My observations and interviews with residents and agricultural extension officers also suggest that the oneage-cohort-pine-plantations raise the risk of landslides. The state forest corporation expands the area under pine to increase resin production and since pine forests are not prone to timber thefts. Residents of various villages noted that landslides occurred particularly frequently in pine forests. They explained the occurrence of several landslides on steep slopes after prolonged rainfall with the combination of saturated soils and the large weight of the thick canopies of the densely planted pine trees. These landslides damaged houses, killed people, and prompted the resettlement of an entire hamlet. This issue has not yet been the subject of scientific inquiry. Knowledge on the effects of land cover on landslide erosion is lacking for the whole of SE-Asia, and landslide erosion is generally barely captured in erosion and sediment yield studies due to the studies' limited temporal and spatial scopes (Sidle et al. 2006).

Some of the one-age-cohort-teak-plantations on sedimentary soils in the eastern and southern parts of the catchment also exhibit high erosion rates. I observed this especially at the onset of the rainy season when the soils are exposed as the trees are defoliated. In line with these observations, Schweithelm (1988:39), one of the few watershed experts who raised concerns over state forest management practices in Java, pointedly noted that "evenaged teak plantations are one of the worst land uses possible from a watershed management perspective". Besides dry-season defoliation, the large teak leaves promote erosion. The larger kinetic energy of the throughfall can result in higher levels of splash erosion than in the open field (Miura et al. 2002; Sidle et al. 2006). The few existing studies on erosion in Java's teak plantations (Wolterson 1979; Widjajani et al. 2011) indicate similar erosion rates as measured on rainfed agricultural land by Rijsdijk (2005). Though these results from different sites and researchers cannot be compared directly, they underline my observations.

Whereas state forests have been framed as the epitome of watershed conservation, peasants' mixed forests, which cover substantial portions of the slopy land in the lagoon's catchment and throughout Java, have barely been acknowledged in watershed-related debates. These forests are also not included in forest cover statistics of Java, which only account for state forest territories (see Verburg et al. 1999; MoF 2014; BPS 2015). Many of these often very dense, diverse, and multi-layered small holder forests, which are usually harvested by selective logging, provide better watershed protection than the forest corporation's rotationally clear cut monocultures of teak (Online Resource $8 c+d)$.

\section{Ngaguguntur and agriculture in riparian zones}

Throughout the lagoon's catchment, farmers have over decades enlarged their wet rice fields in valley floors by digging back the foot of the hill slopes. The excavated soil is shovelled directly into channels and streams. This practice is called "ngaguguntur", a Sundanese term referring to "activities where running water in a man-made canal is used to remove and transport any surplus of soil" (Diemont et al. 1991:219). Whereas in case of surface erosion some sediments are stored on the slope or at slope toes before they might enter the river network with long time lags, ngaguguntur puts the entire amount of material directly and immediately into the river network. That is, different from most other sediment sources, the sediment delivery ratio in case of ngaguguntur is $100 \%$. Very few authors have paid attention to this. Diemont et al. (1991) 
linked ngaguguntur to the extraordinary high RSL of the Cimunutur, a tributary of the Citanduy. In addition, Purwanto (1999) documented one ngaguguntur in the Cikumutuk catchment. It comprised $785 \mathrm{~m}^{3}$ of excavated soil $\left(\approx 707\right.$ tons assuming a bulk density of $\left.900 \mathrm{~kg} / \mathrm{m}^{3}\right)$ and contributed significantly to the total RSL.

In some villages covered by my research, tens of thousands of square-metres of hilly land were converted into plain irrigated rice fields through ngaguguntur. The example of a sub-village at the Raja River, a tributary of the Cikawung and Citanduy Rivers, shall illustrate the magnitude of sediments contributed by this practice. Based on information obtained through interviews and mapping in collaboration with local residents, it was estimated that the irrigated agricultural area was expanded by $25,000 \mathrm{~m}^{2}$ through ngaguguntur within three decades. An average excavation depth of $5 \mathrm{~m}$ was estimated. The resulting $125,000 \mathrm{~m}^{3}$ or 112,000 tons of sediments (assuming a bulk density of $900 \mathrm{~kg} / \mathrm{m}^{3}$ as in Purwanto 1999) were put into streams and channels. This amount from one small subvillage corresponds to $1-2 \%$ of the annual RSL of the Citanduy, which was estimated at 5-10 million tons (PRCECI 1987). These sediments were not put into the river within one year but over a period of a few decades. However, considering an estimated number of at least several hundred other sites with similar landscape modifications throughout the catchment, the contribution of ngaguguntur to total RSL is substantial. Following ngaguguntur, mass movements from the considerably steepened slope toes contribute additional sediments for decades.

Agriculture in riparian zones, which is widespread throughout the lagoon's catchment, also contributes to RSL. Farmers move soil onto riverbanks to expand their fields. The soil eroded from these fields during rainfall or flood events directly enters the river. Sediment delivery ratios are thus $100 \%$, as in case of ngaguguntur. In addition, collapsing river banks due to rainfed and irrigated agriculture can be observed along many river sections in the area. Collapsing field terraces in riparian zones were identified as a major source of RSL also elsewhere in Java (Rijsdijk et al. 2007a).

\section{Roads, trails, and settlements}

The expansion of settlements, roads, and trails since the late nineteenth century has likely substantially contributed to lagoon sedimentation. Erosion on residential plots, roads, trails, and embankments is widespread in the study area, especially where sedimentary soils predominate. The contribution of these sediment sources to RSL has long been neglected, but has recently been quantified at a few locations in Java. Rijsdijk et al. (2007b) found that although roads, trails, and settlements together comprised only $5 \%$ of the total area of the upper Konto watershed, they contributed nearly $40 \%$ of the total sediment yield. Purwanto (1999) measured similarly high erosion rates on residential plots in the Cikumutuk catchment. Thus, due attention needs to be paid to these sediment sources.

While reliable data on the areas covered by roads and trails do not exist, settlement areas can be determined based on historical and contemporary maps. I extracted the settlement areas from 23 historical and 41 recent topographic map sheets, using the classification procedures in ArcGIS, and simplified and manually corrected the resulting shapefiles. The results reveal that the total settlement area in the lagoon's catchment more than doubled between 1924/1926 and the 1990 s to about $600 \mathrm{~km}^{2}$ or $13 \%$ of the catchment area. Since many settlements comprise soil conserving house gardens, only a portion of the settlement area is to be regarded as erosion-prone. Assuming that half of the settlement area $(6-7 \%$ of the catchment area) is erosionprone, considering my observation of partly severe erosion from roads and trails, and taking into account the findings of Rijsdijk et al. (2007b), it is likely that roads, trails, and settlements contribute between one-third and half of the sediments entering the lagoon. Yet, after four decades of investments into watershed conservation, the first smallscale pilot initiatives to reduce erosion within settlements were begun only recently.

\section{Volcanic eruptions}

In addition to anthropogenic drivers, volcanic eruptions have contributed to lagoon sedimentation. Following 1000-4000 years of dormancy, Mt. Galunggung in the upper catchment erupted in 1822, 1894, 1918, 1982-83, and 1984 (GVP 2014). Rivers affected by volcanic eruptions exhibit the highest sediment yields (Milliman and Syvitski 1992; Walling and Webb 1996). The kinds, magnitudes, and temporal courses of volcanic eruptions' hydrological effects have been documented elsewhere (Kuenzi et al. 1979; Major et al. 2000; Hayes et al. 2002; Lavigne 2004). Volcanic eruptions supply easily erodible ash and detritus to hill slopes and channels, deposit tephra, and destroy vegetation, which increases run-off and erosion. This, together with pyroclastic flows and lahars and the redevelopment of drainage networks on debris layers, can raise river sediment yields by several hundred orders of magnitude within 2-3 years after eruption and keep them high for decades (ibid.).

The most explosive eruptions of Mt. Galunggung occurred in 1822 and 1982-1983 with tephra volumes of $>1$ billion and $>370$ million $\mathrm{m}^{3}$, respectively. The eruption of 1822 was one of the world's most explosive ones within the last two centuries (Kohno et al. 1999; Wilson 1999). Documentation of this eruption is scarce. The shoreline change analysis in Figs. 1 and 2 does not cover this period. The sediment analysis by Kastanja (2001) 
indicates increased influx of volcanic material, but does not estimate its relative contribution. Yet, the large amount of tephra ejected and a qualitative account of its impacts underline the relevance of this eruption. Junghuhn (1854:98-99) noted that following the eruption " $[\ldots]$ the Tji-Tandui carried tremendous amounts of material into the [...] "Segara Anakan" [...], which hence became much narrower and shallower within a few days [...]." (translated by the author).

More information exists about the eruption of 1982-1983. About 68 million $\mathrm{m}^{3}$ of the tephra was deposited in the Citanduy catchment (Wirosoemarto et al. 1989). This amount (88 million tons, assuming a dry bulk density of $1300 \mathrm{~kg} / \mathrm{m}^{3}$, following Bernard 2013) exceeds the estimated annual sediment input into the SAL (5-10 million tons, PRC-ECI 1987) by a factor of 9-18. Which proportion of this material was carried into the lagoon within what time span is not clearly known. It was estimated that the eruption raised the RSL of the lower Citanduy by one order of magnitude during the year succeeding the eruption (RMI/PRC/ECI 1986, quoted in Schweithelm 1988). While the ash deposited in large parts of the catchment at depths between $1 \mathrm{~cm}$ at Ciamis and $>25 \mathrm{~cm}$ close to the volcano (Katili and Sudradjat 1984; Sudradjat and Tilling 1984) must have raised sediment delivery to the stream network for a rather short period, the material deposited on the slopes of the volcano and in the streams draining them likely raised sediment delivery for at least several years. Stevens (1994) found that the river bed of the lower Citanduy aggradated for a few years following the eruption until 1986/89. It likely took a similar time span until this material reached the lagoon. The eruption of 1984/85 hence raised sediment delivery to the lagoon for several years until the mid-1990s and contributed to the maximum in siltation rates during this period.

\section{River and floodplain modifications}

River straightening and embankments and agricultural reclamation of the lower river basin's floodplains have also accelerated lagoon sedimentation. Having been straightened and embanked, the Citanduy and Cikonde Rivers no longer deposit portions of their sediments in the alluvial swamp lands upstream from the lagoon during storm water flows. Instead, the entire RSL, which is especially high during storm water flows, is transported into the lagoon.

Historical maps from 1857/60 and 1900/1901 show the lower Citanduy River meandering through swamp forests for almost its entire length (Online Resource 9a). A map from 1929 documents the conversion of substantial swamp forest areas along the river into settlements and arable land (Online Resource 9b). In the 1930s, levees were constructed, and the length of the lower Citanduy was shortened through at least 13 meander cut-offs from 51 to $38 \mathrm{~km}$ to reduce flood risk (PRC-ECI 1975). Levee construction continued in the mid-twentieth century, when villages on the opposing river shores engaged in "dike wars", competing in building higher dikes (Schweithelm 1989:14). River and flood plain modifications were pushed forward on a larger scale in the 1970s as part of the Citanduy-I project. An additional 20 meanders were removed, and more swamp land was reclaimed for agriculture (TKA 1989). Furthermore, a floodway was built to divert peak floods of the Citanduy into the Cibeureum River (PRC-ECI 1987). Thus, some sediments are redirected into the northern part of the lagoon, where a larger proportion is deposited instead of being transported out into the ocean. The floodway carries flows 10-15 times per year for 1-10 days (PRC-ECI 1987). Given that these peak floods contribute a large proportion of the total RSL (in 1984/85 two floods contributed $20 \%$ of the annual RSL, PRC-ECI 1987), the floodway has likely accelerated lagoon sedimentation since the 1970s. Levee construction and agricultural reclamation continued in the 1980s. By the 1990s, the lower Citanduy was substantially shortened, completely embanked and lined with settlements for almost its entire length (Online Resource 9c). Also the Cikonde and Cimeneng Rivers were leveed and straightened in the 1980s (Online Resource 10). This increased sediment input to the northern part of the lagoon, which completely silted up in the 1980s/90s (Fig. 1, cf. PRC-ECI 1987:3-11).

While debates continued to focus on upland agriculture, a few project reports acknowledged the contribution of these river regulations to increased lagoon sedimentation (PRC-ECI 1987; ADB 1996a): an unanticipated side effect of the river development projects which "decision makers [had] not fully appreciated" (TKA 1989:vii). The river and floodplain modifications have magnified the impacts of all other drivers of lagoon sedimentation explored in the above sections.

In contrast, the diversion of the Cimeneng/Cikonde River into the Cibeureum River as part of the Segara Anakan Conservation and Development Project in 2002/03 is assumed to have slowed lagoon sedimentation. This diversion was built to redirect the sediments of the Cimeneng/Cikonde River to the western part of the lagoon, from where a larger portion of it is expected to be transported out into the ocean (ADB 1996b, 2006).

\section{Temporal sequence of watershed and lagoon dynamics}

A synopsis of the watershed characteristics and transformations explored in the above sections shows that high RSL and coastal sedimentation are the result of a large range of historical and contemporary drivers. Figure 2 
Fig. 2 Change in the Segara Anakan lagoon's water surface area between $1857 / 60$ and 2013 combined with a record of landscape characteristics, dynamics, and modifications in its catchment area. The interventions marked with * aimed at reducing lagoon sedimentation. All other factors depicted below the diagram appear to be the main drivers of sedimentation. The shading of the bars qualitatively indicates the change in intensity of the single drivers over time (dark colour indicates a high level of intensity of the respective driver during the respective time span)

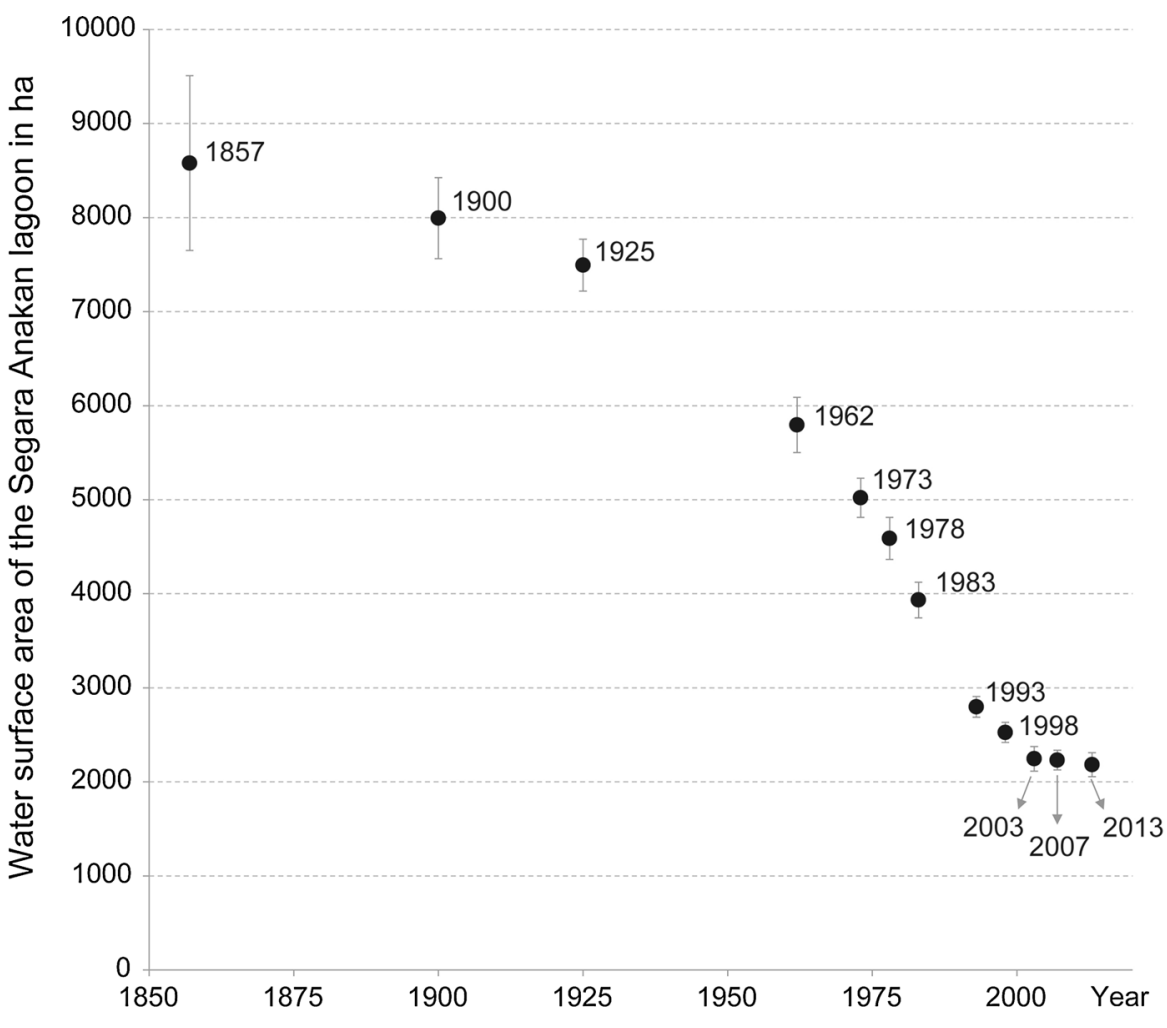

Compulsory coffee cultivation

Large-scale extraction of timber

Establishment of corporate plantations

Railway construction and operation

In-migration

Rainfed agriculture on peasants' private lands

Tree planting and terracing programmes*

Erosion in contested state forests and plantations

State forest management practices

Ngaguguntur and agriculture in riparian zones

Erosion from roads, trails, settlement areas and embankments

Eruptions of Mt. Galunggung 
links these drivers in the form of a time sequence with the siltation of the SAL. Overall, it shows a temporal fit between the drivers identified and the increase in shoreline aggradation. The profound watershed modifications through compulsory coffee cultivation, forest timber extraction, establishment of corporate plantations, railway construction, in-migration, and the expansion of rainfed agriculture from the mid-nineteenth to the early twentieth century appear to have raised aggradation rates. This transformation of the watershed into an increasingly human-dominated landscape has had a lasting impact on sediment production. In addition to rainfed agriculture on peasants' private lands, which has largely been the sole focus of debates and sediment mitigation strategies, various other factors have then contributed to the further increase in aggradation rates during the twentieth century. These include erosion due to conflicts over state forests and plantations, state forest management practices, slope cuts to enlarge agricultural fields in valley floors (ngaguguntur), agriculture in riparian zones, erosion from roads, trails and settlements, and a series of volcanic eruptions. In addition, river channel and floodplain modifications have contributed to lagoon sedimentation. They multiply the effects of all other drivers.

The declining aggradation rates since the early 2000 s depicted in Fig. 2 are mainly related to the dredging of 9.3 million $\mathrm{m}^{3}$ of sediments from a lagoon area of 512 ha in 2002/05 (see ADB 2006). If and to what extent the following factors have also contributed to this recent decline in aggradation rates is uncertain: First, the Cimeneng/Cikonde River was diverted into the Cibeureum River in 2002/03 in order to redirect its sediments to the western part of the lagoon. Second, the proportion of riverine sediments deposited in the lagoon might decline as the water body shrinks. It was estimated in the 1990s that $10-20 \%$ of the sediments are deposited in the lagoon, while the remaining portion is carried out into the ocean (ADB 1996a, b). These proportions might change as the lagoon shrinks. Contemporary hydrodynamics have been modelled (White et al. 1989; Holtermann et al. 2009), but longer-term changes in sediment transport within the lagoon and out into the ocean are uncertain. Third, also the possible effects of the field terracing programmes and increasing tree cover on peasants' private lands since the early 2000 s are uncertain.

\section{Concluding remarks}

Three-fourths of the SAL have silted up since 1857/60. This process accelerated until the late 1980s. It is the result of a much broader range of drivers than commonly assumed. Quantification of the effects of each of these drivers is desirable. However, this remains a challenge for entire river catchments globally. The knowledge of the impacts of watershed modifications on downstream sediment yields and the time lags of such impacts is limited worldwide (Walling and Fang 2003; Bruijnzeel 2004; Sidle et al. 2006; Walling and Collins 2008). Given the decadelong one-sided focus of debates on peasants' private rainfed agricultural lands as the single-most important cause of high RSL and coastal sedimentation in Java, mere identification (necessarily without quantification) of the entire range of causal factors is a crucial basis for further research and more effective management. The synopsis of watershed modifications presented in this paper provides a more complete picture of the causal factors than has been drawn in the frame of long-standing watershed management debates. It suggests that the choice and expectations of societal responses need to be reconsidered. Taking into account the entire range of watershed characteristics and transformations, the potential contribution of soil conservation on peasants' private lands to reducing lagoon sedimentation, while desirable for the sake of sustaining soil productivity, is a priori limited. Reducing the pace of sedimentation to levels seen in the mid-nineteenth century by watershed conservation appears to be unfeasible. Regarding sedimentation not necessarily a threat, but as a transformation that alters but not necessarily destroys the lagoon ecosystem and local livelihood opportunities appears to be a good starting point for further debates over environmental management alternatives.

The case presented illustrates the large breadth of factors to be considered in exploring interlinked watershed-coastal dynamics. It shows that debates, research, and political action can be confined to very few factors for decades while neglecting others. This limits the effectiveness of environmental management. In such contexts, debates must be broadened by open-ended research that explores the whole record of past and contemporary landscape characteristics and modifications in the entire watershed, including their underlying causes. This requires a combination of knowledge from a large range of sources and interdisciplinary approaches linking physical processes with societal dynamics.

Acknowledgments Thanks to Michael Flitner and Kathleen Schwerdtner-Máñez-Costa for discussions which contributed to the initiation of this research, and to Ulrich Scholz, Jill Heyde, Sarah Wise, Seth Gustafson, Silja Klepp, and two anonymous reviewers for their feedback on earlier versions of the manuscript. The research was part of the Indonesian-German research programme SPICE II + III (Science for the Protection of Indonesian Coastal Marine Ecosystems) and sponsored by the German Federal Ministry of Education and Research (Grant-No. 08F0391A/03F0644B). The author was also supported by the Bremen International Graduate School for Marine Sciences (GLOMAR), which is funded by the German Research Foundation (DFG) within the frame of the Excellence Initiative by the 
German federal and state governments to promote science and research at German universities.

Open Access This article is distributed under the terms of the Creative Commons Attribution 4.0 International License (http://crea tivecommons.org/licenses/by/4.0/), which permits unrestricted use, distribution, and reproduction in any medium, provided you give appropriate credit to the original author(s) and the source, provide a link to the Creative Commons license, and indicate if changes were made.

\section{References}

ADB (1996a) Reevaluation of the lower Citanduy Irrigation Project (Loan No. 479-INO) in Indonesia. Reevaluation Study Series (Number 23). Asian Development Bank (ADB)

ADB (1996b) Report and recommendation of the president to the board of directors on proposed loans and technical assistance grant to the Republic of Indonesia for the Segara Anakan Conservation and Development Project. Asian Development Bank

ADB (2006) Indonesia: Segara Anakan Conservation and Development Project. Completion Report. Asian Development Bank

AGS (1945) Special Report No. 76: railways-Java. Applied Geographical Section, Southwest Pacific Area

BAKOSURTANAL (1997-1999) Peta Rupabumi, topographic map produced by the Badan Koordinasi Survey dan Pemetaan Nasional (BAKOSURTANAL), based on surveys in 1993-1994, 1:25,000, 41 map sheets

Barbier EB (1990) The farm-level economics of soil conservation: the uplands of Java. Land Econ 66:199-211. doi:10.2307/3146369

Bernard B (2013) Homemade ashmeter: a low-cost, high-efficiency solution to improve tephra field-data collection for contemporary explosive eruptions. J Appl Volcanol 2:1. doi:10.1186/21915040-2-1

Bird ECF, Soegiarto KA, Rosengren N (eds) (1982) Proceedings of the workshop on coastal resources management in the Cilacap Region. Universitas Gadjah Mada, Yogyakarta, Indonesia, 20-24 August 1980, 1982. Lembaga Penelitian Indonesia, United Nations University, Yogyakarta

Boomgaard P (1988) Forest and forestry in colonial Java: 1677-1942. In: Dargavel J, Dixon JA, Semple N (eds) Changing tropical forests. Historical perspectives on today's challenges in Asia, Australasia and Oceania. Centre for Resource and Environmental Studies, Canberra, pp 59-87

Boomgaard P, van Zanden JL (1990) Food crops and arable lands, Java 1815-1942. Changing economy in Indonesia. A selection of statistical source material from the early 19th century up to 1940 , vol 10. The Royal Tropical Institute, Amsterdam

BPS (2015) Luas Kawasan Hutan dan Perairan1 Menurut Provinsi. Badan Pusat Statistik (BPS). http://www.bps.go.id/linkTabelSta tis/view/id/1716. Accessed July 232015

Bruijnzeel LAS (2004) Hydrological functions of tropical forests: not seeing the soil for the trees? Agric Ecosyst Environ 104:185-228. doi:10.1016/j.agee.2004.01.015

Cooke RU (1992) Common Ground, shared inheritance: research imperatives for environmental Geography. Trans Instit British Geographers 17:131-151. doi:10.2307/622542

Coster C (1938) Bovengrondsche afstrooming en erosie op Java. Tectona 31:613-728

De Haan JH (1936) Afvoerverhoudingen van rivieren in het Alpenland en op Java. Tectona 29:557-588

Dewi KT, Mueller A, Auliaherliaty L (1979) The late quaternary development of the Segara Anakan Lagoon, Southern Java.
Paper presented at the annual general meeting of Asia oceania geosciences society (AOGS)

Diemont WH, Smiet AC, Nurdin (1991) Re-thinking erosion on Java. Neth J Agric Sci 39:213-224

Donner W (1987) Land use and environment in Indonesia. C. Hurst and Company, London

Fasseur C (1992) The politics of colonial exploitation: Java, the Dutch, and the Cultivation System. Dutch edition: Elson RE (ed) Studies on Southeast Asia (trans: Elson RE, Kraal A). Studies on Southeast Asia, Southeast Asia Program Publications. Cornell University Press, New York

Geertz C (1971) Agricultural involution. The processes of ecological change in Indonesia. University of California Press, Berkeley, Los Angeles and London

GVP (2014) Galunggung. Global Volcanism Program, National Museum of Natural History, Smithsonian Institution. http:// volcano.si.edu/. Accessed 21 Nov 2014

Hajer MA (2000) The politics of environmental discourse. Ecological modernization and the policy process. Reprinted edn. Clarendon Press, Oxford

Hayes SK, Montgomery DR, Newhall CG (2002) Fluvial sediment transport and deposition following the 1991 eruption of Mount Pinatubo. Geomorphology 45:211-224. doi:10.1016/S0169$555 \mathrm{X}(01) 00155-6$

Hollerwöger F (1964) The accelerated growth of river deltas in Java. Indones J Geogr 4:1-15

Holtermann P, Burchard H, Jennerjahn T (2009) Hydrodynamics of the Segara Anakan lagoon. Reg Environ Change 9:245-258. doi:10.1007/s10113-008-0075-3

Huszar PC, Cochrane HC (1990) Subsidisation of upland conservation in West Java: the Citanduy II Project. Bull Indones Econ Stud 26:121-132

Jennerjahn TC, Yuwono E (eds) (2009) Segara Anakan, Java, Indonesia, a mangrove-fringed coastal lagoon affected by human activities. Special Issue, Reg Environ Change 9(4)

Junghuhn F (1854) Java. Seine Gestalt, Pflanzendecke und innere Bauart. Nach der zweiten verbesserten Auflage des Holländischen Originals in's Deutsche übertragen von J.K. Hasskarl. Arnoldische Buchhandlung, Leipzig

Kastanja MM (2001) Environmental studies on minerals in the Segara Anakan lagoon, Central Java, Indonesia. M.Sc. Thesis, University of Hamburg

Katili JA, Sudradjat A (1984) Galunggung. The 1982-1983 eruption. Volcanological Survey of Indonesia, Resources Department of Mines and Energy, Republic of Indonesia, Jakarta

Kerbert HJ (1916) De Praktijk van de Boschreserveering. Tectona 8:823-837

Knaap G, van Diessen JR, Leijnse W, Ziellemans MPB (2007) Grote Atlas van de Verenigde Oost-Indische Compagnie/Comprehensive Atlas of the Dutch United East India Company. Volume II: Java en Madoera/Java and Madura. Uitgeverij Maior/Atlas Maior, Voorburg, The Netherlands

Kohno M, Fujii Y, Kusakabe M, Fukuoka T (1999) The last 300-year volcanic signals recorded in an ice core from site H15, Antarctica. J Jpn Soc Snow Ice 61:13-24. doi:10.5331/seppyo. 61.13

Kuenzi WD, Horst OH, McGehee RV (1979) Effect of volcanic activity on fluvial-deltaic sedimentation in a modern arc-trench gap, southwestern Guatemala. Geol Soc Am Bull 90:827-838. doi:10.1130/0016-7606(1979)90<827:EOVAOF $>2.0 . \mathrm{CO} ; 2$

Lavigne F (2004) Rate of sediment yield following small-scale volcanic eruptions: a quantitative assessment at the Merapi and Semeru stratovolcanoes, Java, Indonesia. Earth Surf Proc Land 29:1045-1058. doi:10.1002/esp.1092

Lavigne F, Gunnell Y (2006) Land cover change and abrupt environmental impacts on Javan volcanoes, Indonesia: a long- 
term perspective on recent events. Reg Environ Change 6:86-100. doi:10.1007/s10113-005-0009-2

Lukas MC (2014a) Cartographic reconstruction of historical environmental change. Cartogr Perspect 78:5-24. doi:10.14714/ CP78.1218

Lukas MC (2014b) Eroding battlefields: land degradation in Java reconsidered. Geoforum 56:87-100. doi:10.1016/j.geoforum. 2014.06.010

Lukas MC (2015) Neglected treasures. Linking historical cartography with environmental changes in Java, Indonesia. Cartographica 50:141-162. doi:10.3138/cart.50.3.2891

Magrath W, Arens P (1989) The costs of soil erosion on Java: a natural resource accounting approach. Environment Department working paper, ENV 18. World Bank, Washington, DC

Major JJ, Pierson TC, Dinehart RL, Costa JE (2000) Sediment yield following severe volcanic disturbance-a two-decade perspective from Mount St. Helens. Geology 28:819-822. doi:10.1130/ 0091-7613(2000)28<819:syfsvd>2.0.co;2

Messerli B, Grosjean M, Hofer T, Nunez L, Pfister C (2000) From nature-dominated to human-dominated environmental changes. Quaternary Sci Rev 19:459-479. doi:10.1016/S02773791(99)00075-X

Meybeck M, Vörösmarty C (2005) Fluvial filtering of land-to-ocean fluxes: from natural Holocene variations to Anthropocene. CR Geosci 337:107-123. doi:10.1016/j.crte.2004.09.016

Milliman JD, Farnsworth KL (2011) River discharge to the coastal ocean. A global synthesis. Cambridge University Press, New York

Milliman JD, Syvitski JPM (1992) Geomorphic/tectonic control of sediment discharge to the ocean: the importance of small mountainous rivers. J Geol 100:525-544. doi:10.1086/629606

Milliman JD, Farnsworth KL, Albertin CS (1999) Flux and fate of fluvial sediments leaving large islands in the East Indies. J Sea Res 41:97-107. doi:10.1016/S1385-1101(98)00040-9

Miura S, Hirai K, Yamada T (2002) Transport rates of surface materials on steep forested slopes induced by raindrop splash erosion. J For Res 7:201-211. doi:10.1007/bf02763133

MoF (2014) Statistik Kementerian Kehutanan Tahun 2013 (Ministry of Forestry Statistics). Kementerian Kehutanan (Ministry of Forestry), Jakarta

Nibbering JW (1988) Forest degradation and reforestation in a highland area in Java. In: Dargavel J, Dixon K, Semple N (eds) Changing tropical forests. Historical perspectives on today's challenges in Asia, Australasia and Oceanea. Centre for Resource and Environmental Studies, Australian National University, Canberra, pp 155-177

Nibbering JW, de Graaf J (1998) Simulating the past: reconstructing historical land use and modeling hydrological trends in a watershed area in Java. Environ Hist 4:251-278. doi:10.3197/ 096734098779555600

Olive CA (1997) Land use change and sustainable development in Segara Anakan, Java, Indonesia: Interactions among society, environment and development. Ph.D. Thesis, University of Waterloo

Palmer AW (1959) The Sundanese village. In: Skinner GW (ed) Local, ethnic, and national loyalities in village Indonesia: a symposium. Cultural Report Series. Yale University, Southeast Asia Studies and Institute of Pacific Relations, New York, pp 42-51

Palte JGL (1989) Upland farming on Java, Indonesia. A socioeconomic study of upland agriculture and subsistence under population pressure. Ph.D. Thesis, University of Utrecht

Peluso NL (1992) Rich forests, poor people. Resource control and resistance in Java. University of California Press, Berkeley, Los Angeles

Prakoso SH (1954) Memorandum masalah pembukaan illegaal tanah hutan setjara besar-besaran di Jawa (The problem of illegal deforestation on a large scale in Java). Rimba Indonesia. J For III:109-119

PRC-ECI (1975) The Citanduy River Basin development project. Master Plan. PRC Engineering Consultants Inc, Banjar

PRC-ECI (1987) Segara Anakan Engineering Measures Study. Main Report. PRC Engineering Consultants, Inc. and Ministry of Public Works Indonesia, Denver, USA and Banjar, Indonesia

Purwanto E (1999) Erosion, sediment delivery and soil conservation in an upland agricultural catchment in West Java, Indonesia. A hydrological approach in a socio-economic context. Ph.D. Thesis, Vrije Universiteit

Raffles TS (1817) The history of Java. Black, Parbury and Allen, London

Repetto R (1986) Soil loss and population pressure on Java. Ambio 15:14-18. doi:10.2307/4313201

Rijsdijk A (2005) Evaluating sediment sources and delivery in a tropical volcanic watershed. Paper presented at the proceedings of symposium $\mathrm{S} 1$ held during the seventh IAHS scientific assembly at Foz do Iguaçu, Brazil, April 2005

Rijsdijk A, Bruijnzeel LAS, Prins TM (2007a) Sediment yield from gullies, riparian mass wasting and bank erosion in the Upper Konto catchment, East Java, Indonesia. Geomorphology 87:38-52. doi:10.1016/j.geomorph.2006.06.041

Rijsdijk A, Bruijnzeel LAS, Sutoto CK (2007b) Runoff and sediment yield from rural roads, trails and settlements in the upper Konto catchment, East Java, Indonesia. Geomorphology 87:28-37. doi:10.1016/j.geomorph.2006.06.040

Roessel BWP (1927) Hydrologische cijfers en beschouwingen. Tectona 20:507-527

Rudiarto I, Doppler W (2013) Impact of land use change in accelerating soil erosion in Indonesian upland area: a case of Dieng Plateau, Central Java-Indonesia. Int J AgriSci 3:558-576

Scholz U (1998) Die feuchten Tropen. Das Geographische Seminar. Westermann Schulbuchverlag GmbH, Braunschweig

Schweithelm J (1988) Hydrology, soil erosion and sedimentation in the Citanduy Basin: a watershed management perspective. Resources Management International Inc, Lashburn

Schweithelm J (1989) Watershed land use and coastal sedimentation: the Citanduy/Segara Anakan System. Trop Coast Area Manag 4:13-16

Sidle RC, Ziegler AD, Negishi JN, Nik AR, Siew R, Turkelboom F (2006) Erosion processes in steep terrain-truths, myths, and uncertainties related to forest management in Southeast Asia. For Ecol Manag 224:199-225. doi:10.1016/j.foreco.2005.12.019

Smiet AC (1990) Forest ecology on Java: conversion and usage in a historical perspective. J Trop For Sci 2:286-302

Steup FKM (1927) Hydrologische beschouwingen. Tectona 20:969-974

Stevens MA (1994) The Citanduy, Indonesia—one tough river. In: Schumm SA, Winkley BR (eds) The variability of large alluvial rivers. ASCE Press, New York, pp 201-219

Sudradjat A, Tilling R (1984) Volcanic hazards in Indonesia: the 1982-83 eruption of Galunggung. Episodes 7:13-19. doi:10. 1007/978-3-642-73759-6_9

TKA (1989) Laporan Akhir Proyek Citanduy. Propinsi Jawa Barat. Tim Koordinasi Wilayah, Bandung

USAID (1985) Citanduy II assessment. Special evaluation. Washington

U.S.-Army (1938-44) Topographical map of Java, Middle (and West), Reprints based on maps prepared by the Topographic Service in the Netherlands East Indies (TDNI), Land tax revision brigades; mainly based on surveys in 1924-26; 1:50,000; 23 map sheets, retrieved from Netherlands Royal Tropical Institute (KIT) and the Indonesian National Library

Van Dijk AIJM (2002) Water and sediment dynamics in benchterraced agricultural steeplands in West Java, Indonesia. Ph.D. Thesis, Vrije Universiteit, Amsterdam 
Van Doorn J, Hendrix WJ (1983) The emergence of a dependent economy. Consequences of the opening up of West Priangan, Java, to the process of modernization. The Comparative Asian Studies Programme (CASP), 9. CASP, Faculty of Social Sciences, Erasmus University, Rotterdam

Van Goor CP, Kartasubrata J, Effendi M (1982) Indonesian forestry abstracts. Dutch literature until about 1960. Centre for Agricultural Publishing and Documentation, Wageningen

Van Schaik A (1986) Colonial control and peasant resources in Java: agricultural involution reconsidered, vol 14. Koninklijk Nederlands Aardrijkskundig Genootschap/Instituut voor Sociale Geografie, Universiteit van Amsterdam, Amsterdam, Nederlandse geografische studies

Verburg PH, Veldkamp T, Bouma J (1999) Land use change under conditions of high population pressure: the case of Java. Glob Environ Change 9:303-312. doi:10.1016/S0959-3780(99)001752

Walling DE, Collins AL (2008) The catchment sediment budget as a management tool. Environ Sci Policy 11:136-143. doi:10.1016/j. envsci.2007.10.004

Walling DE, Fang D (2003) Recent trends in the suspended sediment loads of the world's rivers. Global Planet Change 39:111-126. doi:10.1016/S0921-8181(03)00020-1

Walling DE, Webb BW (1996) Erosion and sediment yield: a global overview. In: Walling DE, Webb BW (eds) Proceedings of an international symposium on erosion and sediment yield: global and regional perspectives, Exeter, UK, 15-19 July 1996.
International Association of Hydrological Sciences Publications 236, pp 3-19

White AT, Martosubroto P, Sadorra MSM (eds) (1989) The coastal environmental profile of Segara Anakan-Cilacap, South Java, Indonesia. Association of Southeast Asian Nations/United States Coastal Resources Management Project, Technical Publications Series 4. ICLARM, Manila

Widjajani BW, Wisnubroto EI, Sukresno Utomo WH (2011) The sustainability of teak forest management in Cepu, Central Java, Indonesia: a soil resources point of view. J Basic Appl Sci Res 1:1207-1213

Widjoyo N (1970) Population trends in Indonesia. Cornell University Press, Ithaca

Wilson RM (1999) Variation of surface air temperatures in relation to El Niño and cataclysmic volcanic eruptions, 1796-1882. J Atmos Solar Terr Phys 61:1307-1319. doi:10.1016/S13646826(99)00055-3

Wirosoemarto S, Siswoko, Ramu KV, Nichols P (1989) Citanduy River Basin. Watershed erosion and sedimentation. Paper presented at the international symposium on erosion and volcanic debris flow technology, Yogyakarta, Indonesia, 31 July-2 August 1989

Wolterson JF (1979) Soil erosion in the teak forests of Java. Rapport van het Rijksinstituut voor Onderzoek in de Bos- en Landschapsbouw "De Dorschkamp", 197. Rijksinstituut voor onderzoek in de bosen landschapsbouw "De Dorschkamp", Wageningen 